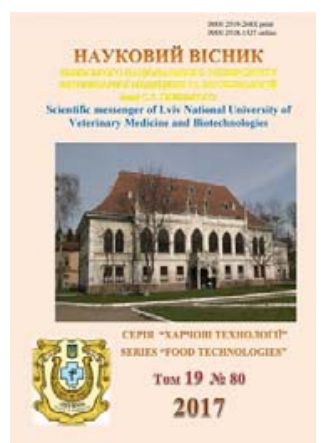

Науковий вісник Львівського національного університету ветеринарної медицини та біотехнологій імені С.3. Гжицького

Scientific Messenger of Lviv National University of Veterinary Medicine and Biotechnologies

doi:10.15421/nvlvet8026

ISSN 2519-268X print

ISSN 2518-1327 online

$\underline{\text { http://nvlvet.com.ua/ }}$

УДК 664.36:665.347.8:665.222

\title{
Розробка складу жирової композиції для емульсійної системи 3 добавками похідних гідробіонтів
}

\author{
Д.П. Крамаренко, Н.І. Гіренко \\ kramarenko_dp@ukr.net \\ Харківський державний університет харчування та торгівлі, \\ вул. Клочківська, 333, Харків, 61051, Україна
}

Поліненасичені жирні кислоти можуть надходити в організм із раціоном у різних кількостях, але реалізація їх біологічної дії можлива тільки при дотриманні конкретного співвідношення $\omega-3$ i $\omega-6$ жирних кислот. Співвідношення $\omega-6: \omega-3$ y раціоні здорової людини повинне бути 10:1, а для лікувального харчування - від 3:1 до 5:1. Природні рослинні олії й тваринні жири не забезпечують рекомендоване фахівиями співвідношення $\omega-6$ i $\omega-3$ жирних кислот. Авторами статті розроблено склад купажу жирової композичії для емульсійної системи з добавками похідних гідробіонтів, що забезпечують збалансований склад $\omega-3$ і лінійного програмування розраховано склад купажу жирової композииії, щео забезпечує необхідне для здоров'я людини співвідношення поліненасичених жирних кислот. Методом газорідинної хроматографії визначена відповідність отриманого складу купажу розрахованим значенням. Установлено, що запропонована жирова композиція може бути рекомендована для щзоденного й профілактичного харчування населення, оскільки співвіднотення поліненасичених жирних кислот $\omega-6: \omega-3$ складає 10:1, щңо повністю забезпечує потреби людського організму в незамінних жирних кислотах. Проведене дослідження вплив добавки емульгатора-стабілізатора - комплексу дистильованих моноглицеридів жирних кислот (E 471) на температуру плавлення й застигання жирової композииії і отримані формули, щчо описують ичі залежності. Доведене ше введення даного емульгатора до складу жирової композищї приводить до підвищення як температури плавлення так $i$ застигання. Визначене щзо введення E 471 у кількості до 4...5\% у розроблену жирову композицію забезпечує оптимальний інтервал температур застигання й плавлення для засвоєння жирової композииії організмом людини. Розроблена жирова композиція передбачається для використання як жсирового компонента емульсійного продукту з добавками похідних гідробіонтів для використання в складі фаршевих і пастоподібних мас.

Ключові слова: поліненасичені жирні кислоти, жирнокислотний склад, сонящникова олія, свинячий жир, оптимізований склад, емульгатор, температура застигання, температура плавлення.

\section{Разработка состава жировой композиции для эмульсионной системы с добавками производных гидробионтов}

\author{
Д.П. Крамаренко, Н.І. Гиренко \\ kramarenko_dp@ukr.net \\ Харьковский государственный университет питания и торговли, \\ ул. Клочковская, 333, Харьков, 61051, Украина
}

\begin{abstract}
Полиненасыщенные жирные кислоты могут поступать в организм с рационом в разных количествах, но реализация их биологического действия возможна только при соблюдении конкретного соотночения $\omega-3$ и $\omega-6$ жирных кислот. Соотношение $\omega-6: \omega-3$ в рационе здорового человека должно быть 10:1, а для лечебного питания - от 3:1 до 5:1. Природные растительные масла и животные жиры не обеспечивают рекомендованное специалистами соотношение $\omega-6$ и $\omega$-3 жирных кислот. Авторами статьи разработан состав купажа жировой композиции для эмульсионной системы с добавками
\end{abstract}

Citation:

Kramarenko, D.P., Hirenko, N.I. (2017). Development of fat composition content for the emulsion system with additives of hydrobiont derivatives. Scientific Messenger LNUVMB, 19(80), 123-127. 
производных гидробионтов, обеспечивающчие сбалансированный состав населения Украины жиры - растительное масло и свиной жир. Методом линейного программирования рассчитан состав купажа жировой композиции, обеспечивающей необходимое для здоровья человека соотношение полиненасыиенньх жирных кислот. Методом газожидкостной хроматографии определено соответствие полученного состава купажа рассчитанным значениям. Установлено, что предложенная жировая композиция может быть рекомендована для ежедневного и профилактического питания населения, поскольку соотношение полиненасыщенных жирных кислот 10:1, что полностью обеспечивает потребности человеческого организма в незаменимых жирных кислотах. Проведено исследование влияние добавки эмульгатора и стабилизатора - комплекса дистиллированных моноглицеридов жирных кислот (Е 471) на температуру плавления и застывания жировой композиции и получены формуль описывающие эти зависимости. Доказано что введение данного эмульгатора в состав жировой композиции приводит к повыиению как температуры плавления так и застывания. Определено что введение Е 471 в количестве до 4 ...5\% в разработанную жировую композицию обеспечивает оптимальный интервал температур застывания и плавления для усвоения жировой композиции организмом человека. Разработанная жировая композиция предполагается для использования в качестве жирового компонента эмульсионного продукта с добавками производных гидробионтов для использования в составе фариевых и пастообразных масс.

Ключевые слова: полиненасыщенные жирные кислоты, жирнокислотный состав, подсолнечное масло, свиной жир, оптимизированный состав, эмульгатор, температура застывания, температура плавления.

\title{
Development of fat composition content for the emulsion system with additives of hydrobiont derivatives
}

\author{
D.P. Kramarenko, N.I. Hirenko \\ kramarenko_dp@ukr.net \\ Kharkov State University of Food Technology and Trade, \\ Klochkovsky Str., 333, Kharkov, 61051, Ukraine
}

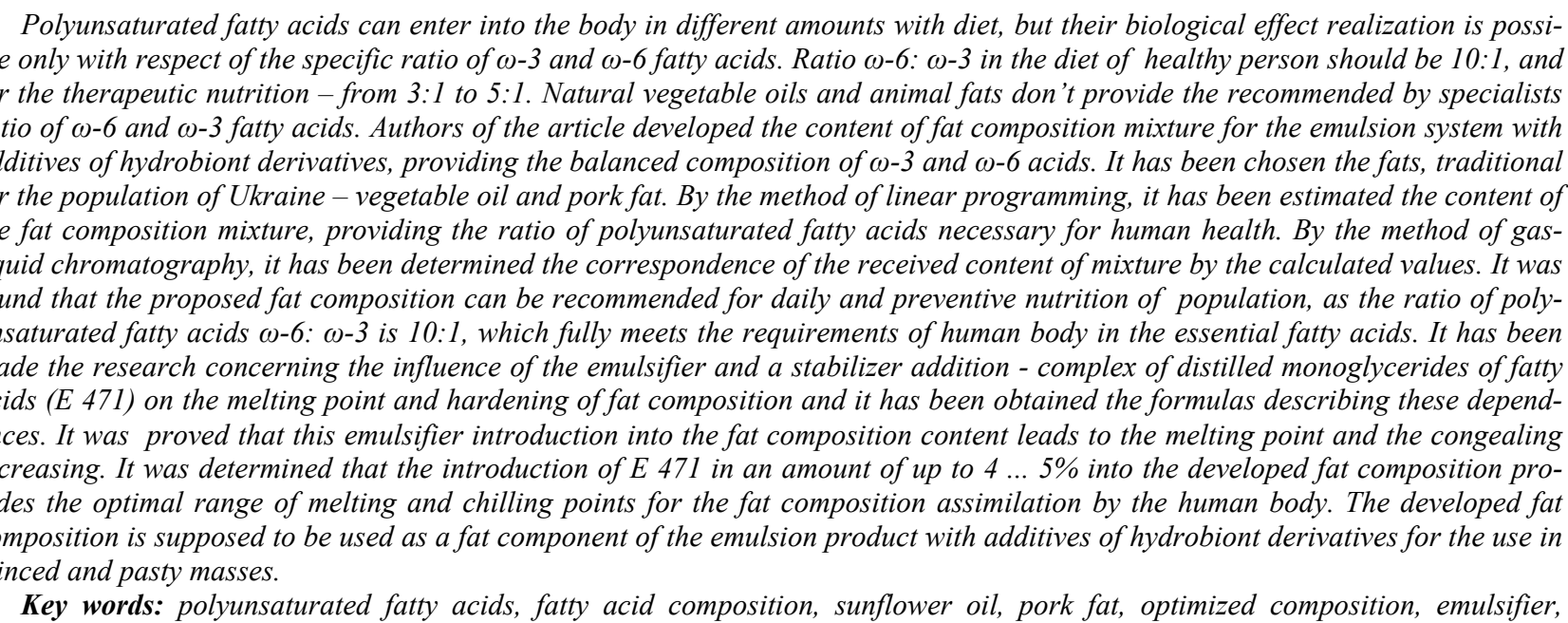
chilling point, melting point.

\section{Вступ}

Функціональні продукти харчування - харчові продукти, призначені для систематичного вживання в складі харчових раціонів усіма віковими групами здорового населення, що знижують ризик розвитку захворювань, пов'язаних з харчуванням, що зберігають і поліпшують здоров'я за рахунок наявності в їх складі фізіологічно функціональних харчових інгредієнтів.

У цей час продукти функціонального харчування становлять не більш 3\% усіх відомих харчових продуктів. Прогнозується, що в найближчі один-два десятиліття потенціал ринку даних продуктів перевищить 30\% від усіх реалізованих продуктів харчування. Однією із продуктових груп, що найбільш динамічно розбудовуються, у сегменті функціональних продук- тів харчування $\epsilon$ масложирова, тому розширення асортименту масложирових продуктів, корисних для здоров'я, має значні перспективи (Campos et al., 2008). Поряд із цим, функціональні жирові продукти можуть бути використані як компоненти різноманітних напівфабрикатів у тому числі фаршів і закусочних паст.

Основними технологічними рішеннями при розробці функціональних жирових продуктів $є$ зниження загальної калорійності, виключення холестерину, підвищення вмісту поліненасичених жирних кислот (ПНЖК), зниження змісту трансізомерів жирних кислот, використання фізіологічно функціональних інгредієнтів: вітамінів (А, Д, групи В, фолієвої кислоти, токоферолів), мінералів (кальцію й ін.), харчових волокон, фітостеринів і ї ефірів, пребіотиків і ін. (Lauretani et al., 2007). 
За останні роки отримано багато нових даних про вплив ПНЖК на організм, виявлені клітинні й молекулярні механізми їх профілактичного й лікувального ефектів (Weaver et al., 2009). Поліненасичені жирні кислоти виявляють сприятливий вплив при атеросклерозі, коронарній хворобі серця, артеріальної гіпертонії, цукровому діабеті другого типу, ожирінні, хронічних запальних захворюваннях, нейродегенеративних захворюваннях (зокрема при хворобі Альцгеймера), очних хворобах, знижують ризик розвитку інфаркту міокарда, інсульту, деяких онкологічних захворювань (Bakhtin et al., 2006; Chapkin et al., 2008). Збільшення споживання поліненасичених жирних кислот супроводжується зниженням рівня ліпідів плазми крові; отримані дані, що свідчать про те, що більшість ефектів гіполіпідемічних препаратів обумовлене впливом ПНЖК (Bakhtin et al., 2006; Campos et al., 2008). ПНЖК сприяють зниженню артеріального тиску й підвищення тонусу парасимпатичної нервової системи. У ряді досліджень показане, що $\omega-3$ жирні кислоти попереджають розвиток серцевих аритмій (Weaver et al., 2009; Ipatova et al., 2009).

ПНЖК можуть надходити в організм із раціоном у різних кількостях, але реалізація їх біологічної дії можлива тільки при дотриманні конкретного співвідношення $\omega-3$ i $\omega-6$ жирних кислот. Відповідно до рекомендацій Інституту харчування співвідношення $\omega-6: \omega-3$ у раціоні здорової людини повинне бути 10:1, а для лікувального харчування - від 3:1 до 5:1. Адекватний рівень споживання $\omega-3$ і $\omega-6$ жирних кислот 11 г у добу (з них $\omega-3-1$ г) (Campos et al., 2008).

Природні рослинні олії не забезпечують рекомендоване фахівцями співвідношення $\omega-6$ і $\omega-3$ жирних кислот. Відомо, що основною рослинною олією в харчуванні населення України $€$ соняшникова, яка містить достатню кількість жирних кислот сімейства $\omega-6$ (олеінову 19,4 мас.\% і лінолеву 65,9 мас.\% ) i дуже мало кислот сімейства $\omega-3$, що належать до незамінних.

Традиційно для розв'язку завдання по збалансованості жирнокислотного складу жирових продуктів і напівфабрикатів використовують різні комбінації рослинних жирів (Kondratova et al., 2010). Враховуючи, що в раціоні харчування людини рослинні жири повинні комбінуватися із тваринами, а найбільше ефективно жири засвоюються в емульгованому стані (Rogovet al., 2007), ми вирішили розробити жирову основу з комбінацією соняшникової олії й традиційного для кухні України свинячого жиру.

Метою проведених досліджень стала розробка складу жирової композиції для емульсійної системи 3 добавками похідних гідробіонтів, як функціонального напівфабрикату для створення фаршевих і пастоподібних продуктів харчування, здатних задовольнити потребу організму в ПНЖК. Досягнення поставленої мети обумовило розв'язання наступних завдань:

- розрахунки купажу композиції рослинного й тваринного жирів, що має збалансований жирнокислотний склад по співвідношенню $\omega-3$ і $\omega-6$ жирних кислот;

- одержання й дослідження жирнокислотного складу жирової композиції;
- підбір ефективного й безпечного емульгатора й дослідження впливу його кількості на зміни показників температури плавлення й застигання жирової композиції.

\section{Матеріал і методи досліджень}

Об'єктами дослідження були обрані як найпоширеніші на території України рослинна соняшникова олія i тваринний пряжений свинячий жир, які були використані у купажі жирової композиції для забезпечення необхідного баланс ПНЖК.

На першому етапі за літературним даними про жирнокислотний склад підібраних жирів було здійснене моделювання методом лінійного програмування. Для розрахунків використовували наступні формули:

$$
\begin{gathered}
\frac{m_{1} \times C_{\omega 6}^{1}+m_{2} \times C_{\omega 6}^{2}}{m_{1} \times C_{\omega 3}^{1}+m_{2} \times C_{\omega 3}^{2}}=10 ;(1) \\
m_{1}+m_{2}=1,(2)
\end{gathered}
$$

де $\mathrm{m}_{1}, \mathrm{~m}_{2}$ - відповідно масова частка рослинної олії і свинячого жиру; $\mathrm{C}_{\text {ws }}^{1}, \mathrm{C}_{\text {ws }}^{2}-$ кількість жирних кислот групи $\omega-6$ у рослинної олії і свинячого жиру, мас\%; $\mathrm{C}_{\omega 3}^{1}, \mathrm{C}_{\omega 3}^{2}-$ кількість жирних кислот групи $\omega-3$ у рослинної олії й свинячого жиру, мас $\%$;

На другому етапі був досліджений жирнокислотний склад жирової композиції методом газорідинної хроматографії. Приготування метилових ефірів жирних кислот здійснювали відповідно до ГОСТ 316652012. Умови проведення ГЖХ аналізу: кварцовий капілярний стовпчик: довжина - 100 м, діаметр 0,25 мм, нанесена фаза - ціанопропілфенілполісилаксан. ПІД детектор, газоносій - азот, об'єм проби, що вводиться, - 1 мкл. Початкова температура термостата колонок $-140{ }^{\circ} \mathrm{C}$ протягом 4 хв, потім програмований підйом температури зі швидкістю $3{ }^{\circ} \mathrm{C} / \mathrm{xв}$ до $180{ }^{\circ} \mathrm{C}$ - ізотермічний режим протягом 40 хв. Програмований підйом температури зі швидкістю $3{ }^{\circ} \mathrm{C} / \mathrm{xв} \mathrm{до}$ $240{ }^{\circ} \mathrm{C}$ - ізотермічний режим - 25 хв.

Ідентифікацію окремих компонентів проводили 3 використанням еталонних сумішей метилових ефірів жирних кислот Restek 35077 i Restek 35079, а також на підставі відомих літературних даних по індексах утримання.

Кількісний вміст жирних кислот (ЖК) у досліджуваних зразках визначали методом внутрішньої нормалізації за допомогою пакета Unichrome®.

На третьому етапі проводили дослідження впливу емульгатора i стабілізатора на зміну температури плавлення і застигання розробленої суміші жирів. У якості емульгатора-стабілізатора нами була використана суміш комплексу дистильованих моногліцеридів жирних кислот (Е 471), так ця добавка має натуральне походження і належить до групи безпечних добавок (Horalchuk, 2016).

Температуру плавлення й застигання визначали за стандартною методикою ДСТУ 4463:2005 «Маргарини, жири кондитерські та для молочної промисловості. Правила приймання та методи випробування». 


\section{Результати та їх обговорення}

Результати аналізу розрахункового жирнокислотного складу жирової композиції та порівняння з розрахунковим складом і літературними даними по ба- жаному співвідношенні насичених жирних кислот (НЖК), мононенасичених жирних кислот (МНЖК) i поліненасічених жирних кислот (ПНЖК) наведені й таблиці 1.

Таблиия 1

Співвідношення жирних кислот у різних продуктах, $(\mathrm{n}=5, \mathrm{P} \leq \mathbf{0 , 0 5})$

\begin{tabular}{|c|c|c|c|c|c|c|c|c|}
\hline \multirow{2}{*}{ Продукт } & \multicolumn{3}{|c|}{$\begin{array}{c}\text { Бажане співвідношення, } \\
\text { \% }\end{array}$} & \multicolumn{3}{|c|}{$\begin{array}{c}\text { Дійсне співвідношення, } \\
\% \\
\end{array}$} & \multirow{2}{*}{$\begin{array}{c}\text { Бажане спів- } \\
\text { відношення } \\
\omega-3: \omega-6 \text { кислот }\end{array}$} & \multirow{2}{*}{$\begin{array}{c}\text { Реальне } \\
\text { співвід- } \\
\text { ношення } \\
\omega-3: \omega-6 \\
\text { кислот }\end{array}$} \\
\hline & НЖК & МНЖК & ПНЖК & НЖК & МНЖК & ПНЖК & & \\
\hline Рафінована рослинна олія & \multirow{4}{*}{30} & \multirow{4}{*}{$50 \ldots 60$} & \multirow{4}{*}{$10 \ldots 20$} & 8,19 & 48,48 & 43,33 & \multirow{4}{*}{$1: 10$} & $0: 59,81$ \\
\hline Жир свинячий & & & & 41,38 & 47,56 & 11,06 & & $1: 0,13$ \\
\hline Молочний жир & & & & 67,7 & 28,6 & 3,7 & & $1: 6,01$ \\
\hline Жирова композиція & & & & 15,93 & 50,04 & 34,02 & & $1: 10,17$ \\
\hline
\end{tabular}

Дані таблиці свідчать, що природні рослинні олії і тваринні жири не збалансовані по співвідношенню жирних кислот. Комбінуючи рослинну олію і тваринний жир нам вдалося отримати жирову композицію 3 найбільш збалансованим складом жирних кислот. В отриманій жировій композиції в 1,88 разів менше НЖК і в 1,29...1,59 разів більше ПНЖК в порівнянні 3 бажаними показниками, але зважаючи на високу біологічну цінність ПНЖК та надмірну кількість НЖК в раціоні Українців, ми вважаємо результат купажування задовільним.
Так як розроблена жирова композиція планується до використання в емульсійних продуктах та напівфабрикатах, ми досліджували вплив кількості емульгатора-стабілізатора на показники температури застигання та плавлення. Результати проведених досліджень наведені на рисунку 1.

Як можна бачити 3 наведених даних підвищення концентрації емульгатора-стабілізатора призводить для збільшення як температури застигання, так і плавлення. Найбільш інтенсивно підвищуються показники температур плавлення і застигання до 5\% відсотків емульгатора.

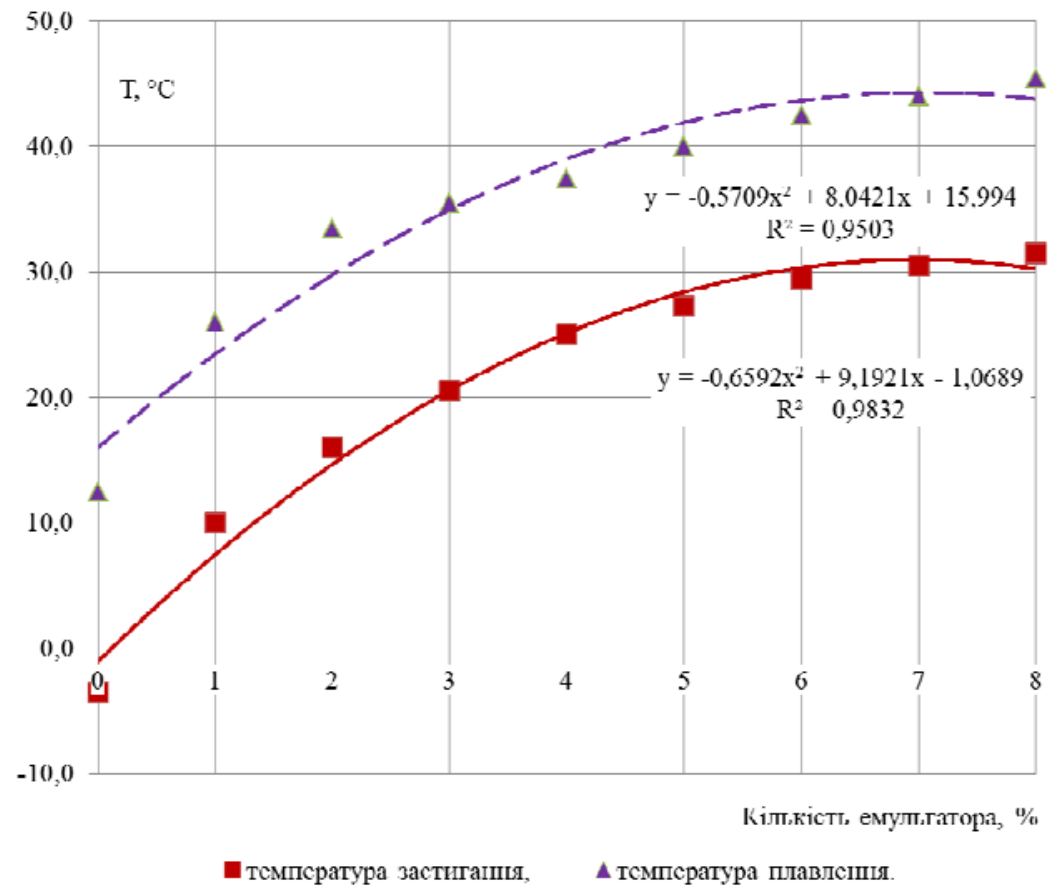

Рис. 1. Вплив кількості емульгатора Е471 на температури плавлення і застигання жирової композиції

Як свідчать данні фізіологів, засвоюваність жирів організмом людини залежить від температури плавлення, і найбільшою засвоюваністю володіють жири 3 температурою плавлення до $37 \ldots 40{ }^{\circ} \mathrm{C}$. Цей інтервал температур відповідає концентрації емульгатора в 4...5\%. Отримані данні також можна використати для визначення оптимального інтервалу температур для проведення процесу емульгування.

\section{Висновки}

Таким чином, спроектована жирова композиція може бути використана як жировий компонент при розробці технологій продуктів функціонального харчування, що забезпечують організм людини ПНЖК виду $\omega-3$ і $\omega-6$ у рекомендованому співвідношенні. 
Визначені залежності змін температур застигання та плавлення в залежності від кількості емульгатора можна використати при розробці технологій емульсійних продуктів з розробленою жировою композицією. Визначено що введення Е 471 у кількості до $4 . .5 \%$ у розроблену жирову композицію забезпечує оптимальний інтервал температур застигання й плавлення для засвоєння жирової композиції організмом людини.

Перспективи подальших досліджень. Розроблена жирова композиція передбачається для використання як жирового компонента емульсійного продукту 3 добавками похідних гідробіонтів для використання в складі фаршевих і пастоподібних мас. Тому необхідно провести підбір згущувачів і стабілізаторів водної фази емульсійних систем. В якості згущувачівстабілізаторів передбачається використання продуктів переробки гідробіонтів як речовин, що мають в своєму складі як поверхнево активні речовини так і комплекс біологічно активних речовин (Kramarenko and Hirenko, 2017).

\section{Бібліографічні посилання}

Campos, H., Baylin, A., Willett, W.C. (2008). Alphalinolenic acid and risk of nonfatal acute myocardial infarction. Circulation. 118, 339-345.

Lauretani, F., Bandmelli, F., Benedetta, B. (2007). Omega-6 and omega-3 fatty acids predict accelerated decline of peripheral nerve function in older persons. Journal of Neurology. 14(7), 801-808.

Weaver, K.L., Ivester, P., Seeds, M. (2009). Effect of dietary fatty acids on inflammatory gene expression in healthy humans. J. Biol. Chem. 284(23), 1540015407.

Chapkin, R.S., McMurray, D.N., Davidson, L.A. (2008). Bioactive dietary long-chain fatty acids: Emerging mechanisms of action. British Journal of Nutrition. 100(6), 1152-1157.

Bakhtin, Yu.V., Budaeva, I.I., Vereshchagin, A.L. (2006). The effectiveness of the use of cedar oil in the complex treatment of patients with hypertension. Voprosy pitaniya [Nutrition]. 75(1), 51-53 (in Russian).

Ipatova, 1.G., Kochetkova, A.A., Nechaev, A.P., Tutel'yan, V.A., Yegorova, Ye.Yu., Zhukova, Ye.Ye., Saratikov, A.S. (2009). Zhirovyye produkty dlya zdorovogo pitaniya. Sovremennyy vzglyad [Fat products for a healthy diet. The modern view]. Moscow, DeLi print Publ. (in Russian).

Kondratova, I.I., Babodey, V.N., Golubeva, V.S., Khonyak, D.A., Nikolaevich, L.N. (2010). Blended vegetable oil for gerodietary nutrition. Pishchevaya promyshlennost': nauka i tekhnologii [Food industry: science and technology]. 4, 21-26 (in Russian).

Rogov, I.A., Antipov, L.V., Dunchenko, N.I. (2007). Himiya pishchi [Chemistry of food]. Moscow, Kolos (in Russian).

Horalchuk, A.B. (2016). Naukove obgruntuvannia tekhnolohii napivfabrykativ zabyvnykh dlia kulinarnoi ta kondyterskoi produktsii z poli faznoiu dyspersnoiu strukturoiu. Dokt, Diss. [Scientific substantiation of technologies of semifinished products for culinary and confectionery products with poly phase dispersed structure. Doct. Diss.]. Kharkiv (in Ukrainian).

Nechaev, A.P., Traubenberh, S.E., Kochetkova, A.A. (2007). Pishhevaja himija [Food chemistry]. Moscow, GIORD (in Russian).

Kramarenko, D.P., Hirenko, N.I. (2017). Doslidzhennia poverkhnevoi aktyvnosti dobavok $\mathrm{z}$ hidrobiontiv [Investigation of the surface activity of additives from hydrobionts]. Scientific Letters of Academic Society of Michal Baludansky. 5(4), 46-48 (in Ukrainian). Received 25.09.2017

Received in revised form 24.10.2017 Accepted 28.10.2017 